\title{
ANALISIS DAMPAK REHABILITASI HUTAN MANGROVE TERHADAP PENDAPATAN MASYARAKAT DESA LUBUK KERTANG KABUPATEN LANGKAT
}

\author{
ROSWITA HAFNI \\ Dosen Fakultas Ekonomi Universitas Muhammadiyah Suamtera Utara \\ Email : roswita_ayu@yahoo.com
}

\begin{abstract}
ABSTRAK
Luas ekosistem hutan mangrove yang tersebar dibeberapa pulau yang ada di Indonesia sekitar 4.251.011 Ha. Tetapi, lebih dari setengah luas ekosistem hutan mangrove yang ada di Indonesia ternyata dalam kondisi rusak parah, Hutan mangrove di Sumareta Utara terletak di sepanjang pantai timur dari data BP2HM seluas 199.478,32 ha. Dan Kabupaten Langkat memiliki luas mangrove yang paling dominan yakni 50.650,93 ha. Sejak tahun 2006 hutan mangrove telah dialihfungsikan menjadi perkebunan kelapa sawit. Akibat alih fungsi hutan mangrove itu, kondisi lahan menjadi rusak, Secara ekonomi sumberdaya alam yang menjadi sumber pendapatan menjadi berkurang secara signifikan.mata pencaharian nelayan di enam desa, menurun drastis.

Tujuan penelitian ini adalah untuk mengetahui keadaan hutan mangrove, serta bagaimana dampak rehabilitasi hutan mangrove terhadap pendapatan masyarakat nelayan tradisional, khususnya di Desa Lubuk Kertang Kecamatan Brandan Barat Kabupaten Langkat Provinsi Sumatera Utara.

Penelitian ini bersifat deskriptif dan yang menjadi populasi dalam penelitian ini adalah seluruh wilayah hutan mangrove yang berada di Desa Lubuk Kertang Kecamatan Brandan Barat sebanyak $746 \mathrm{kk}$ nelayan. Jumlah sampel dengan tekhnik slovin sebanyak $70 \mathrm{kk}$. Tekhnik analisis data yang digunakan adalah analisis komparatif.

Hasil penelitian menunjukkan bahwa : (1) Keadaan hutan mangrove di Desa Lubuk Kertang Kecamatan Brandan Barat dengan luas kerusakan hutan mangrove $740 \mathrm{Ha}(61,67 \%)$ dari luas seluruh hutan mangrove $1200 \mathrm{Ha}$. Kerusakan hutan mangrove tergolong kondisi berat $528 \mathrm{Ha}(71,35 \%)$ dari luas kerusakan mangrove $740 \mathrm{Ha}$. (2) Rusaknya hutan mangrove berdampak negatif bagi nelayan Desa lubuk Kertang, dengan nilai sig sebesar 0,020<0,05, Hal ini menyatakan bahwa korelasi antara sebelum rehabilitasi dan setelah rehabilitasi hutan mangrove berhubungan secara nyata. Sebelum kerusakan terjadi pendapatan masyarakat nelayan cukup memadai untuk memenuhi kebutuhan hidupnya, namun setelah kerusakan terjadi pendapatan masyarakat nelayan menurun drastic.
\end{abstract}

Kata kunci : studi, kerusakan, hutan mangrove

\section{A. PENDAHULUAN}

Luas ekosistem hutan mangrove yang tersebar dibeberapa pulau yang ada di Indonesia sekitar 4.251.011 Ha. Dan lebih setengah luas ekosistem hutan mangrove tersebut dalam kondisi rusak parah. Hutan mangrove di Sumareta Utara terletak di sepanjang pantai timur, dari data BP2HM seluas 199.478 ha. hutan yang rusak seluas 59.077 hektare atau $33 \%$, dan seluas 47.868 hektare sudah direhabilitasi. Kabupaten Langkat memiliki luas mangrove yang paling 
dominan yakni 50.650,93 ha, dan menempati urutan pertama lahan hutan mangrove paling rusak di Sumatera Utara, yakni seluas 13.526 hektare," Republika.co.id, Jumat(29/4). atau sekitar 25 persen. Sedangkan, yang dalam kondisi sedang ada 23.564 hektare dan dalam proses rehabilitasi seluas4.415ha, yang terluas rusak dan direhabilitasi di kabupaten Langkat ada di desa Lubuk Kertang kecamatan Brandan Barat. Keadaan hutan mangrove di desa tersebut tergolong kondisi kerusakan berat $528 \mathrm{Ha}$ dari luas kerusakan hutan mangrove 740 $\mathrm{Ha}$, dari seluruh hutan mangrove $1200 \mathrm{Ha}$. Kerusakan tersebut akibat dialihfungsikan menjadi perkebunan kelapa sawit dan tambak. Akibatnya, kondisi lahan menjadi rusak, mata pencaharian nelayan, menurun drastis.

Perluasan tanaman sawit telah menghancurkan 75 persen atau 62.800 hektar kawasan pesisir dan kawasan tutupan hutan tersisa hanya 25 persen (Kompas, 30 Jan 2010). Ekspansi kebun sawit menyebabkan perkampungan nelayan jadi rentan terhadap banjir, dan mereka makin sulit mencari ikan dan udang di wilayah tangkapnya sendiri. Konversi lahan besarbesaran itu telah menimbulkan berbagai macam persoalan. Secara ekologis, konversi telah menyebabkan menurunnya fungsi ekologis daerah tersebut. Masyarakat sekitar juga telah merasa termarjinalkan karena penguasaan dan akses terhadap wilayah semakin tertutup. Secara ekonomi mereka juga merasa dirugikan karena sumberdaya alam yang menjadi sumber pendapatan mereka, seperti nilai ekonomi mangrove, kepiting bakau, udang, ikan, dll., menjadi berkurang secara signifikan.

Lubuk Kertang adalah desa pesisir yang letaknya terjauh dari kecamatan Brandan Barat Kabupaten Langkat Provinsi Sumatera Utara, diantara desa 2 lain, yaitu 14,0 km, Dengan luas daerah 34\% dari total luas wilayah kecamatan, yaitu $3.026 \mathrm{Ha}$, merupakan desa yang terluas diantara desa2 dan kelurahan lainnya, dan dengan penggunaan lahan yang berbedabeda.

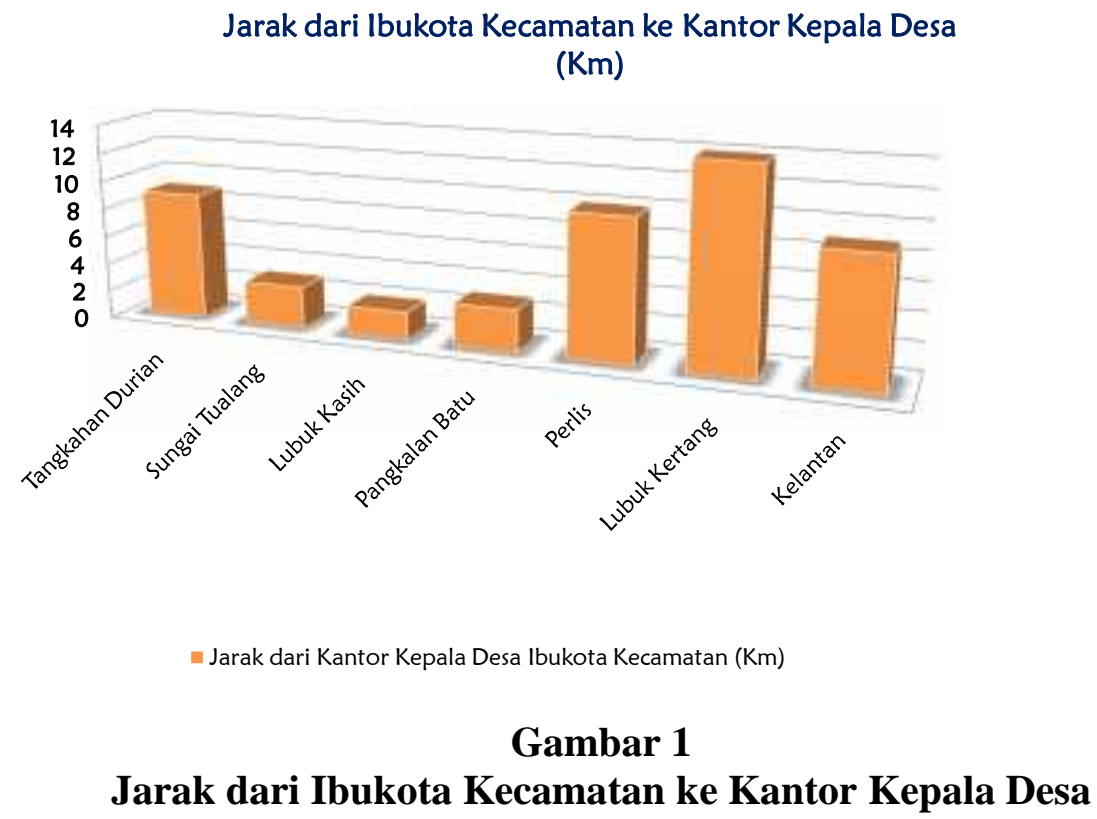


Luas, Jumlah Penduduk, dan Kepadatan Penduduk Dirinci Menurut Desa / Kelurahan Tahun 2015

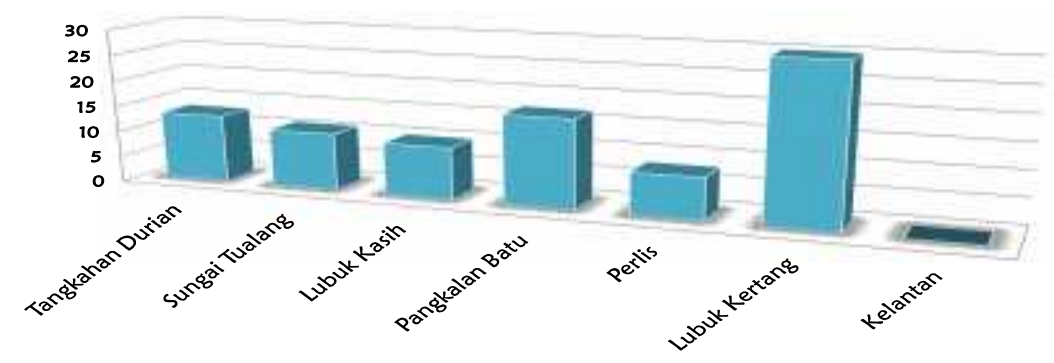

- Luas (Km2)

\section{Gambar 2}

Luas, Jumlah Penduduk dan Kepadatan Penduduk Dirinci Menurut Desa/Kelurahan Tahun 2015

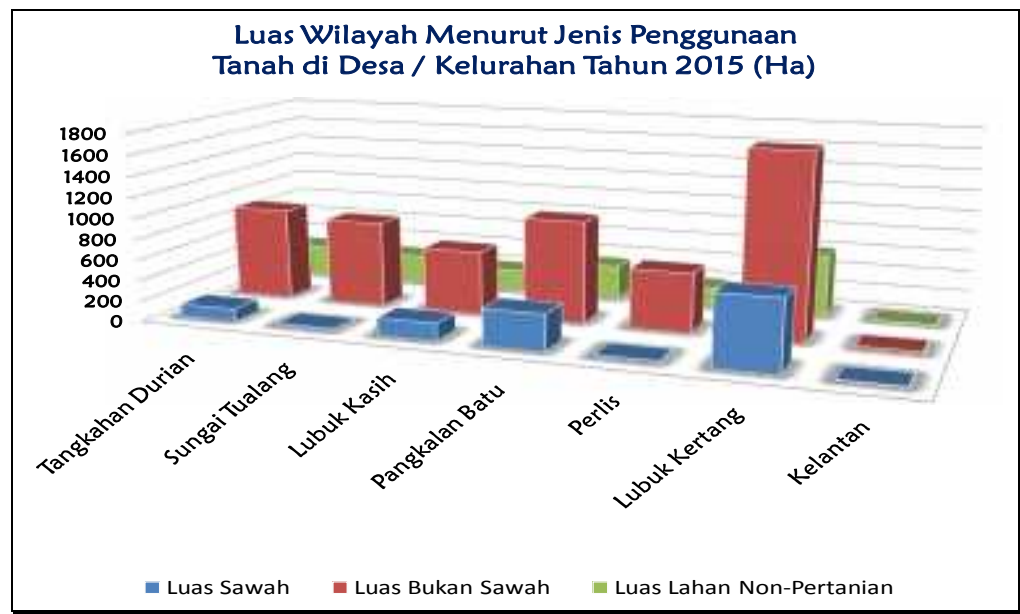

\section{Gambar 3}

Luas Wilayah Menurut Jenis Penggunaan Tanah di Desa/Kelurahan Tahun 2015 (Ha)

Jumlah Penduduk, Rumah Tangga Dirinci Menurut Desa / Kelurahan Tahun 2015

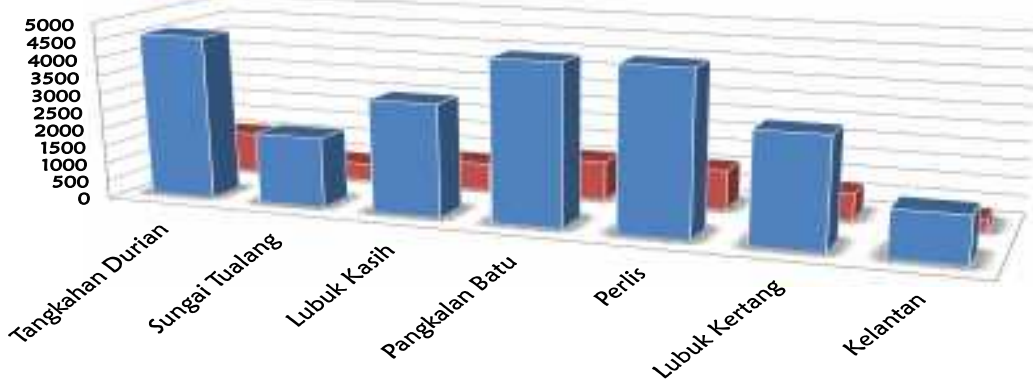

- Penduduk $\quad$ Jumlah Rumah Tangga

\section{Gambar 4}

Jumlah Penduduk, Rumah Tangga Dirinci Menurut Desa/Kelurahan Tahun 2015 
Namun jumlah penduduknya tidak sebanyak desa atau kelurahan lainnya, yaitu 3.039 jiwa, dan jumlah Kepala Keluarga $746 \mathrm{KK}$ yang rata-rata per rumah tangga 4 jiwa. (Data Statistik Daerah Kecamatan Brandan Barat 2016).

Mata pencaharian masyarakat di kecamatan tersebut, untuk nelayan menurut jenis usahanya $92 \%$ adalah sebagai nelayan laut, ini disebabkan bahwa posisi daerah tersebut berada dipesisir laut dan sungai, selebihnya menangkap ikan di sungai, petani ikan tambak, ikan kolam dan sebagainya.

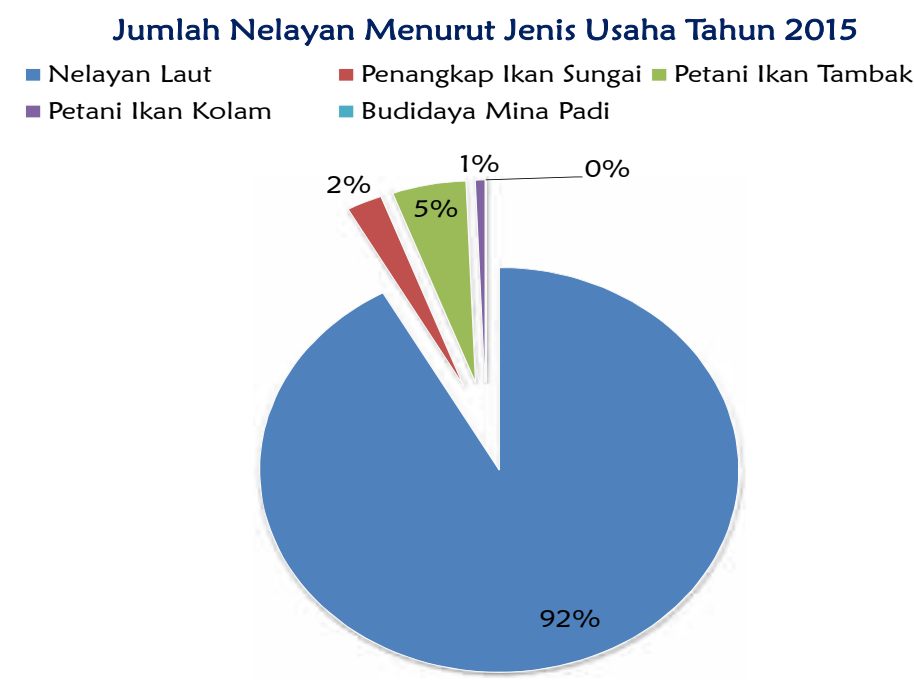

\section{Gambar 5}

\section{Jumlah Nelayan Menurut Jenis Usaha Tahun 2015}

Dari latar belakang diatas, bahwa pendapatan akan masyarakat, akan mempengaruhi keadaan sosial ekonominya, begitu juga masyarakat nelayan, khususnya Desa Lubuk Kertang. Bagaimana pendapatan masyarakat nelayan sebelum direhabilitasi dengan setelah direhabilitasi hutan mangrove didaerah tersebut? Minimnya penghasilan yang diakibatkan oleh rusaknya sebagian besar ekosistem mangrove, para nelayan di daerah tersebut sangat keberatan pembukaan areal perkebunan kelapa sawit maupun pembukaan lahan tambak yang tidak memperhatian aspek lingkungan. Hal ini berimbas pada kondisi ekonomi nelayan pesisir yang mata pencahariannya menangkap ikan di laut. Berkurangnya hasil tangkapan menyebabkan melaut lebih jauh dari pantai sehingga nelayan akan menanggung biaya dan resiko yang dikeluarkan. Dengan demikian ada sebagian masyarakat nelayan yang beralih ke matapencaharian lain

\section{Tujuan}

- Melakukan analisis dari faktor-faktor yang menyebabkan terjadinya kerusakan hutan mangrove di Desa Lubuk Kertang Kecamatan Brandan Barat Kabupaten Langkat.

- Melakukan analisis dampak ekonomi yang di timbulkan dari rusaknya hutan mangrove di Desa Lubuk Kertang

- Melakukan analisis upaya yang di lakukan pemerintah dan masyarakat dalam merehabilitasi hutan mangrove di Desa Lubuk Kertang.

- Melakukan analisis uji beda dalam melihat kondisi perekonomian masyarakat Sebelum kerusakan terjadi pendapatan masyarakat nelayan cukup memadai untuk memenuhi kebutuhan hidupnya, namun setelah kerusakan terjadi pendapatan masyarakat nelayan menurun drastic. 


\section{B. LANDASAN TEORI}

\section{Pengertian Hutan Mangrove}

Mangrove berasal dari kata mangal yang menunjukkan komunitas suatu tumbuhan (Odum. 1983). Davis (1940) dalam Walsh (1974) menyebutkan bahwa kata mangrove merupakan istilah umum untuk pohon yang hidup di daerah yang berlumpur, basah dan terletak di perairan pasang surut daerah tropis, Soerianegara dan Indrawan (1982) menyatakan bahwa hutan mangrove adalah hutan yang tumbuh di daerah pantai, biasanya terdapat di daerah teluk dan di muara sungai yang dicirikan oleh: (1) tidak terpengaruh iklim; (2) dipengaruhi pasang surut; (3) tanah tergenang air laut; (4) tanah rendah pantai; (5) hutan tidak mempunyai struktur tajuk; (6) jenis-jenis pohonnya biasanya terdiri atas api-api (Avicenia Sp), pedada (Sonneratia), bakau (Rhizophora Sp), lacang (Bruguiera $\mathrm{Sp}$ ), nyirih (Xylocarpus Sp), nipah (Nypa Sp) dan lain-lain.

Hutan mangrove adalah tipe hutan yang secara alami dipengaruhi oleh pasang surut air laut, tergenang pada saat pasang naik dan bebas dari genangan pada saat pasang rendah. Ekosistem mangrove adalah suatu sistem yang terdiri atas lingkungan biotik dan abiotik yang saling berinteraksi di dalam suatu habitat mangrove. Hutan mangrove disebut juga "Coastal Woodland" (hutan pantai) atau "Tidal Forest" (hutan surut)/hutan bakau, yang merupakan formasi tumbuhan litoral yang karakteristiknya terdapat di daerah tropika (Saenger,1983).

\section{Fungsi dan Manfaat Hutan mangrove}

Saenger (1983); Salim (1986); dan Naamin (1990) menyatakan bahwa fungsi ekosistem mangrove mencakup: fungsi fisik; menjaga garis pantai agar tetap stabil, melindungi pantai dari erosi laut (abrasi) dan intrusi air laut; dan mengolah bahan limbah. Fungsi biologis ; tempat pembenihan ikan, udang, tempat pemijahan beberapa biota air; tempat bersarangnya burung; habitat alami bagi berbagai jenis biota. Fungsi ekonomi sebagai sumber bahan bakar (arang kayu bakar), pertambakan, tempat pembuatan garam, dan bahan bangunan. Karena karakter pohon mangrove yang khas, ekosistem mangrove berfungsi sebagai peredam gelombang dan badai, pelindung abrasi, penahan lumpur, dan perangkap sedimen. Disamping itu, ekosistem mangrove juga merupakan penghasil detritus dan merupakan daerah asuhan (nursery ground), daerah untuk mencari makan (feeding ground), serta daerah pemijahan (spawning ground) bagi berbagai jenis ikan, udang, dan biota laut lainnya. Juga sebagai pemasok larva ikan, udang, dan sebagai tempat pariwisata.

Menurut Hardjosento (1981) dalam Saenger (1983), hasil dari hutan mangrove dapat berupa kayu, chips, kayu bakar, arang kulit kayu yang menghasilkan tanin (zat penyamak), bahan bangunan sepertui: balok perancah, bangunan, jembatan, balok rel kereta api,pembuatan kapal, tonggak dan atap rumah. Tikar bahkan pagar pun menggunakan jenis yang berasal dari hutan mangrove. Makanan seperti: obat-obatan dan minuman, gula alkohol, asam cuka, obat- obatan. Perikanan seperti: tiang-tiang untuk perangkap ikan, pelampung jaring, pengeringan ikan, jaring dan lantai. Pertanian seperti:, makanan ternak, pupuk. Produksi kertas berbagai macam kertas dsb, Manfaat ekologis hutan mangrove: (a). Sebagai proteksi dari abrasi/erosi, gelombang atau angin kencang, (b). Pengendali intrusi air laut. (c). Habitat berbagai jenis fauna , (d), Sebagai tempat mencari makan, memijah dan berkembang biak berbagaijenis ikan dan udang, (e). Pembangun lahan melalui proses sedimentasi, (f). Pengontrol penyakit malaria, (g). Memelihara kualitas air seperti meredukasi polutan, pencemar air, (h). Penyerap CO2 dan penghasil $\mathrm{O} 2$ yang relatif tinggi disbanding tipe hutan lain. 


\section{Penyebab rusaknya ekosistem mangrove}

Secara garis besar faktor penyebab kerusakan hutan mangrove: (1). Faktor manusia yang merupakan faktor dominan penyebab kerusakan hutan mangrove dalam hal pemanfaatan lahan yang berlebihan. Seperti: a. Keinginan untuk membuat pertambakan dengan lahan yang terbuka dengan harapan ekonomis dan menguntungkan, karena mudah dan murah. b. Kebutuhan kayu bakar yang sangat mendesak untuk rumah tangga, karena tidak ada pohon lain di sekitarnya yang bisa ditebang. c. Rendahnya pengetahuan masyarakat akan berbagai fungsi hutan mangrove. d. Adanya kesenjangan sosial antara petani tambak tradisional dengan pengusaha tambak modern, sehingga terjadi proses jual beli lahan yang sudah tidak rasional. (2) Faktor alam, seperti : banjir, kekeringan dan hama penyakit, yang merupakan faktor penyebab yang relatif kecil (Tirtakusumah, 1994).

\section{Konversi Hutan Mangrove,}

Hampir semua bentuk pemanfaatan lahan di wilayah pesisir berasal dari konversi hutan mangrove. Hutan mangrove sepanjang pantai telah dikonversi menjadi kawasan permukiman, tambak, kawasan industri, pelabuhan, lading garam dan lain-lain. Kebanyakan konversi hutan mangrove menjadi bentuk pemanfaatan lain belum banyak ditata berdasarkan kemampuan dan peruntukan pembangunan, sehingga menimbulkan kondisi yang kurang menguntungkan dilihat dari manfaat regional dan nasional. Oleh karena itu pemanfaatan hutan mangrove yang tersisa atau upaya rehabilitasinya harus sesuai dengan potensi dan rencana pemanfaatan yang lainnya dengan mempertimbangkan kelestarian ekosistem, manfaat ekonomi dan penguasaan teknologi.

\section{Rehabilitasi Hutan Mangrove}

Menurut Peraturan Menteri Kehutanan No.03/MENHUT-V/2004 rehabilitasi hutan mangrove adalah upaya mengembalikan fungsi hutan mangrove yang mengalami degradasi, kepada kondisi yang dianggap baik dan mampu mengemban fungsi ekologis dan ekonomis. Untuk memulihkan dan meningkatkan fungsi lindung, fungsi pelestarian dan fungsi produksi (Kementrian Lingkungan Hidup, 1994). dan telah dirintis sejak tahun 1960 di kawasan pantai utara Pulau Jawa.Sekitar 20.000 ha hutan mangrove yang rusak di pantai utara Pulau Jawa dilaporkan telah berhasil direhabilitasi dengan menggunakan tanaman utama Rhizophora spp dan Avicennia spp dengan persentumbuh hasil penanaman berkisar antara $60-70 \%$.

Rehabilitasi hutan mangrove merupakan bagian dari sistem pengelolaan hutan mangrove yang merupakan bagian integral dari pengelolaan kawasan pesisir secara terpadu yang ditempatkan pada kerangka Daerah Aliran Sungai (DAS) sebagai keseimbangan lingkungan dan tata air.

\section{Permasalahan Sosial Ekonomi}

Meningkatkannya pertumbuhan penduduk dan laju pembangunan di wilayah pesisir, menyebabkan timbulnya ketidak seimbangan antara permintaan kebutuhan hidup, kesempatan dengan persediaan sumber daya alam pesisir yang ada. Upaya pengembangan pertanian intensif (coastalagriculture) yang dilakukan tidak optimal, dan kegiatan serta kesempatan yang berorientasi kelautan juga masih terbatas dikembangkan. Akibat keadaan tersebut menyebabkan terus meningkatnya pengrusakan ekosistem kawasan pesisir dan lautan khususnya kawasan hutan mangrove, disamping penyebab terjadinya alih fungsi lahan menjadi perkebunan ataupun tambak - tambak ikan. 


\section{Teori Pendapatan}

Menurut Sukirno (2006:47) pendapatan adalah jumlah penghasilan yang diterima oleh penduduk atas prestasi kerjanya selama satu periode tertentu, baik harian, mingguan, bulanan ataupun tahunan. Beberapa klasifikasi pendapatan antara lain: 1) Pendapatan pribadi, yaitu; semua jenis pendapatan yang diperoleh tanpa memberikan suatu kegiatan apapun yang diterima penduduk suatu Negara. 2) Pendapatan disposibel, yaitu; pendapatan pribadi dikurangi pajak yang harus dibayarkan oleh para penerima pendapatan, sisa pendapatan yang siap dibelanjakan inilah yang dinamakan pendapatan disposibel. 3) Pendapatan nasional, yaitu; nilai seluruh barang-barang jadi dan jasa-jasa yang diproduksikan oleh suatu Negara dalam satu tahun.

Masalah pendapatan tidak hanya dilihat dari jumlahnya saja, tetapi bagaimana distribusi pendapatan yang diterima oleh masyarakat. Dewasa ini sumber pendapatan sebagian besar rumah tangga di pedesaan tidak hanya dari satu sumber, melainkan dari beberapa sumber atau dapat dikatakan rumah tangga melakukan diversifikasi pekerjaan atau memiliki aneka ragam sumber pendapatan (Susilowati dkk, 2002). Pendapatan rumah tangga pertanian ditentukan oleh tingkat upah sebagai penerimaan faktor produksi tenaga kerja. Nilai sewa tanah sebagai penerimaan dari penguasaan asset produktif lahan pertanian. Dengan demikian tingkat pendapatan rumah tangga pedesaan sangat dipengaruhi oleh tingkat penguasaan faktor produksi. Menurut Malian dan Siregar (2000) pendapatan rumah petani pinggiran perkotaan juga bersumber dari tiga kegiatan utama, yaitu kegiatan dalam usaha tani sendiri (on-farm), kegiatan pertanian di luar usaha tani sendiri (off-farm) dan kegiatan di luar sektor pertanian (non-farm). Untuk petani yang berada di pedesaan, pendapatan yang bersumber dari kegiatan on-farm dan off-farm umumnya mencapai lebih dari 90 persen.

\section{Kerangka konseptual}

Dalam rangka pengelolaan dan pelestarian mangrove, terdapat dua konsep utama yang dapat diterapkan. Kedua konsep ini pada dasarnya memberikan legitimasi dan pengertian bahwa mangrove sangat memerlukan pengelolaan dan perlindungan agar dapat tetap lestari. Kedua konsep tersebut adalah perlindungan hutan mangrove dan rehabilitasi hutan mangrove. Masalahnya bagaimana dengan pendapatan masyarakat nelayan didaerah tersebut sebelum di Rehabilitasi Hutan Mangrove dengan sesudah di Rehabilitasi Hutan Mangrove.

\section{METODOLOGI}

Defenisi operasional adalah; Rehabilitasi hutan mangrove dan Pendapatan masyarakat, sedangkan tempat penelitian di lakukan di Desa Lubuk Kertang Kecamatan Brandan Barat Kabupaten Langkat. Populasi penelitian yakni Daerah Rehabilitasi hutan mangrove dengan jumlah 746 Kepala Keluarga (KK) dan. Dan sampelnya dengan tekhnik slovin, error 10\% sebanyak $70 \mathrm{KK}$ sebagai nelayan. menggunakan tekhnik simple random sampling. Tekhnik pengumpulan data yang digunakan Wawancara, Kuesioner, dan Data Sekunder. Sedangkan tekhnik analisis data adalah analisis diskriptif dan analisis komparatif

\section{HASIL DAN PEMBAHASAN}

\section{Analisis Disktiptif}

\section{a. Keadaan Hutan Mangrove di Desa Lubuk Kertang}

Berdasarkan hasil penelitian di lapangan kondisi hutan mangrove di Desa Lubuk Kertang mengalami kerusakan yang sangat parah, dengan upaya pemerintah setempat dalam melaksanakan pemeliharaan hutan mangrove dengan sistem tebang 
pilih. Akan tetapi karena kurangnya kesadaran masyarakat bahwa pentingya hutan mangrove dalam ekosistem menyebabkan program yang dilaksakan pemerintah tidak berjalan dengan lancar. Luas hutan mangrove yang ada di Desa Lubuk Kertang pada tahun 2010 adalah 1200 Ha.

Kondisi hutan mangrove di Desa Lubuk Kertang, dengan kondisi(1) Baik sekitar $235 \mathrm{Ha}(19,58 \%)$ yang dimana persentasi penutupan vegetasi hutan mangrove di lahan kawasan hutan mangrove $275 \%$ dan kerapatan pohon mangrove $\geq 1500$ Pohon/Ha (2) kondisi sedang sekitar $225 \mathrm{Ha}(18,75 \%)$ yang dimana persentasi penutupan vegetasi hutan mangrove di lahan kawasan ekosistem hutan mangrove antara $50 \%$ sampai $75 \%$ dan kerapatan pohon mangrove antara 1000 sampai 1500 Pohon/Ha; dan (3) kondisi rusak sekitar $740 \mathrm{Ha}(61,67 \%)$ yang dimana persentasi penutupan vegetasi hutan mangrove di lahan kawasan ekosistem hutan mangrove $<50 \%$ dan kerapatan pohon mangrove $<1000$ Pohon/Ha.

\section{- Pemanfaatan Sumberdaya Ekosistem Hutan Mangrove}

Pemanfaatan sumberdaya ekosistem hutan mangrove oleh pemduduk di Desa Lubuk Kertang Kecamatan Brandan Barat dapat diketahui dari hasil wawancara kepada responden dari sampel penelitian yang berjumlah $70 \mathrm{KK}$ adalah $100 \%$, artinya, ternyata semua sumberdaya hutan mangrove di Desa Lubuk Kertang Kecamatan Brandan Barat bermanfaat buat masyarakat. Dengan masing-masing pemanfaatannya untuk kayu, buah, biji dan akar ada sebanyak $20 \%$, sedangkan yang memanfaatkan biota laut yang terdapat di dalam ekosistem hutan mangrove sebanyak $80 \%$, Hal ini berarti masyarakat ternyata lebih dominan memanfaatkan biota laut yang terdapat di dalam ekosistem hutan mangrove, mereka menyatakan bahwa mangrove adalah sumber kehidupan kami.

- Penyebab Kerusakan Hutan Mangrove

Penyebab kerusakan hutan mangrove, terjadinya eksplotasi sangat besar, sebanyak $80 \%$, dengan pembukaan lahan mangrove untuk tambak maupun perkebunan sawit $20 \%$. Ternyata lebih dominan terjadinya eksploitasi hutan mangrove di Desa Lubuk Kertang.

\section{- Pengaruh Kerusakan Hutan Mangrove Terhadap Nelayan Tradisional}

Kerusakan hutan mangrove terhadap nelayan tradisional sangat mempengaruhi hasil tangkapan mereka 100\%. Masyarakat sangat membutuhkan mangrove untuk biota-biota laut yang ada di kawasan hutan mangrove.

- Kerusakan Hutan Mangrove Mempengaruhi Pendapatan Nelayan Tradisional

Kerusakan hutan mangrove mempengaruhi pendapatan nelayan $100 \%$, karena, jika hasil tangkap mereka berkurang maka pendapatan mereka juga berkurang dari hasil tangkapan mereka tersebut.

- Perubahan Lahan Mangrove Menjadi Tambak Maupun Perkebunan Sawit

Perubahan lahan mangrove menjadi tambak maupun perkebunan sawit awalnya $100 \%$ masyarakat sangat kecewa. Rusaknya hutan mangrove yang ada di Desa Lubuk Kertang akibat dari penebangan liar untuk bahan baku arang dan sebagian kawasan hutan mangrove telah berubah fungsi menjadi areal pertambakan, dan perkebunan sawit, namun masyarakat tidak bisa berbuat apaapa akibat ulah dari beberapa oknum tertentu.

Dari lima dusun didesa tersebut yaitu dusun Janggus, Paluh tabuhan, Tepi gandu, Alur lebah, dan kelapa enam. Dusun yang mengalami kerusakan hutan mangrove yang paling parah adalah Dusun II yaitu Paluh tabuhan yaitu $600 \mathrm{Ha}$, berikutnya dusun III Tepi gandu $290 \mathrm{Ha}$, dan dusun IV Alur lebah 75 Ha.Tingkat kerusakannya berbeda-beda dari ketiga dusun tersebut. 


\section{b. Keadaan Sosial Ekonomi}

Tekanan terhadap kawasan mangrove secara umum disebabkan oleh faktor sosial ekonomi, faktor alam dan faktor kebijakan. Faktor yang paling dominan sebagai faktor penyebab tekanan terhadap kawasan mangrove adalah faktor sosial ekonomi. Kebutuhan akan penghidupan dan kebutuhan sehari-hari menjadi alasan penyebab tekanan terhadap kawasan mangrove terus berlanjut. Mata pencaharian tangkap ikan lepas pantai merupakan pekerjaan utama yang dilakukan masyarakat pesisir (nelayan) atau masyarakat tempatan (masyarakat tempatan adalah penduduk yang tinggal di pantai dan sekitarnya, baik pendatang maupun peduduk asli). Ada tiga sasaran lokasi tempat penangkapan ikan, pertama, area pesisir dan muara sungai; kedua hamparan terumbu karang dan ketiga laut dalam. Nelayan memilih kawasan terumbu karang sebagai lokasi tangkapan karena merupakan tempat perlindungan dan bertelur ikan atau udang. Selain itu juga, di lahan tersebut relatif terlindung dari pengaruh angin terutama saat musim angin Utara dan perairan yang cukup jernih.

\section{c. Manfaat Hutan Mangrove terhadap Nelayan}

Penduduk Desa Lubuk Kertang sebagian besar bermatapencaharian sebagai nelayan yang menggantungkan hidupnya pada sumber daya alam di laut. Masyarakat tersebut berprofesi sebagai nelayan. Ada bermacam-macam nelayan di Desa Lubuk Kertang bila didasarkan pada alat yang digunakan untuk menangkap ikan, Ada nelayan yang menggunakan jaring, cager, beranjang, pancing,cadong, dan lain-lain. Mengingat laut merupakan sumber penghasilan bagi masyarakat Desa Lubuk Kertang, mefreka sangat bergantung pada ketersediaan ikan yang berada di perairan Desa Lubuk Kertang sebagai tempat untuk mendapatkan ikan. Ketersediaan ikan-ikan itu berkaitan erat dengan adanya hutan mangrove karena hutan mangrove sebagai daerah mencari makanan (feeding ground) dan daerah pemijahan (spawning ground) bermacam biota perairan (ikan, udang dan kerang-kerang) baik yang hidup di perairan pantai maupun lepas pantai. Nelayan menyadari betul manfaat hutan mangrove bagi kelangsungan dirinya sebagai nelayan. Sebab hutan mangrove merupakan tempat ikan-ikan mencari makanan dan sebagai daerah pemijahan. Ini berarti bila keberadaan hutan mangrove tidak dijaga dan dilestarikan berarti akan mengancam kelangsungan mereka sebagai nelayan. Lebih-lebih mereka itu masih nelayan tradisional. Sebesar $62,5 \%$ bahwa hutan mangrove sangat bermanfaat sebagai tempat mencari makan dan bertelur bagi biota laut sehingga populasi biota laut tetap terjaga kelestariannya. Sedangkan 37,5\% hutan mangrove sebagai penahan dari abrasi sehingga tidak terjadi banjir ketika mereka mencari ikan

\section{d. Dampak Rusaknya Hutan Mangrove Terhadap Nelayan di Desa Lubuk Kertang}

Hutan mangrove sangat berkaitan erat terhadap nelayan meskipun secara tidak langsung, hutan mangrove merupakan tempat ikan-ikan mencari makanan dan sebagai daerah pemijahan. Ini berarti bila keberadaan hutan mangrove tidak dijaga dan dilestarikan berarti akan mengancam kelangsungan mereka sebagai nelayan. Nelayan merasakan bahwa penghasilannya sebagai nelayan semakin tahun semakin menurun. Salah satu dari sekian sebab penurunan penghasilan nelayan tersebut disebabkan semakin berkurangnya luas hutan mangrove yang berada di Desa Lubuk kertang. Karena adanya penggarapan tambak-tambak barudan penebangan liar yang dilakukan oleh masyarakat. Dampak kerusakan hutan mangrove yang berada di perairan sangat disadari masyarakat nelayan sangat buruk karena populasi 
biota laut semakin berkurang dan 50\% kerusakan hutan mangrove sering menyebabkan terjadi banjir dan jebolnya tambak-tambak sehingga pendapatan ikan maupun kepiting menurun.

Kerusakan hutan mangrove berdampak negatif. Hal itu dirasakan oleh seluruh masyarakat nelayan mempengaruhi penghasilan mereka. Penghasilan mereka mengalami penurunan $50 \%$ bahkan sampai $75 \%$ dari penghasilan mereka dulu sebelum hutan mangrove rusak. Hal ini sesuai dengan yang dijelaskan oleh Dietriech G Bengen dalam bukunya Sinopsis Ekosistem dan Sumber Daya Alam Pesisir dan Laut serta Prinsip Pengelolaannya bahwa kerusakan hutan mangrove menyebabkan tidak berfungsinya daerah mencari makanan dan pengasuhan bagi biota laut dan mengancam regenerasi stok ikan dan udang di perairan lepas pantai yang memerlukan hutan mangrove. Hutan mangrove yang berfungsi sebagai tempat reproduksi biota laut, seperti udang, kepiting dan ikan hampir merata rusak akibat dirambah dan dikonversi dengan tanaman kelapa sawit maupun tambak. Dampak jangka panjang akibat kerusakan lingkungan ini diperkirakan semakin memperburuk tingkat sosial ekonomi nelayan.

\section{e. Hal-hal Utama yang Menjadi Permasalahan dan Penyebab Kerusakan Hutan Mangrove}

- Tekanan penduduk untuk kebutuhan ekonomi yang tinggi sehingga permintaan konversi mangrove juga semakin tinggi.

Penduduk disini lebih mementingkan kebutuhannya sendiri-sendiri dibandingkan kepentingan ekologis dan kepedulian akan dampak lingkungan hidup. Banyaknya pihak yang tidak bertanggung jawab juga dengan meminta untuk mengkonversi lahan mangrove tapi setelah dikonversi lahan tersebut mereka tidak menindak lanjutinya. Mereka lebih paham bahwa manfaat dengan dikonversinya hutan mangrove menjadi tambak dan lahan kelapa sawit akan lebih menguntungkan padahal kalau ditinjau secara keuntungan jangka panjang hutan mangrove akan lebih bermanfaat.

- Perencanaan dan pengelolaan sumber daya pesisir di masa lalu bersifat sangat sektoral.

Pengelolaan yang sektoral ini akan mengakibatkan terjadinya kerusakan hutan mangrove berat yang akan berdampak pada masa yang akan datang. Kemudian rendahnya kesadaran masyarakat tentang konversi dan fungsi ekosistem mangrove

\section{Analisis Komparatif}

Berdasarkan hasil penelitian, mayoritas usia nelayan $>50$ tahun sebanyak $16 \%$, usia 41-50 tahun 40\%, dan usia 31- 40 tahun 30\%, sedangkan untuk usia 20-30 tahun 14\%. Ternyata Nelayan laki-laki $81 \%$, dan ada nelayan perempuan atau19\%. Tingkat pendidikan nelayan Diploma/S1 5\%, SMA 36\%, SMP 11\% dan mayoritas pendidikan nelayannya adalah tingkat SD $48 \%$.

Untuk mengetahui apakah ada dampak rehabilitasi hutan mangrove terhadap pendapatan masyarakat sebelun dan sesudahnya, diperlihatkan pada tabel berikut ini : 
Tabel 1

Uji Komparatif

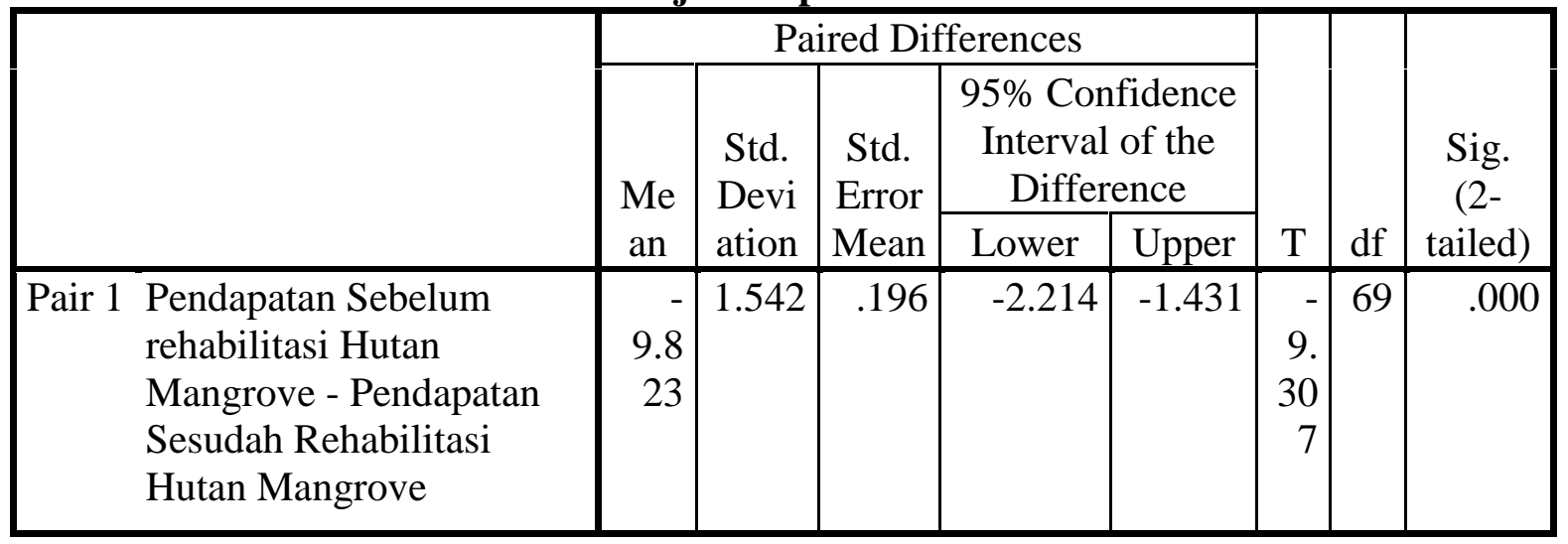

Hipotesis berupa :

1) Ho : $\mathbf{b}=\mathbf{0}$, Rata-rata pendapatan masyarakat nelayan di Desa Lubuk Kertang kecamatan Brandan Barat Kabupaten Langkat sebelum dan sesudah Rehabilitasi Hutan mangrove adalah sama .

2) Ha : $\mathbf{b} \neq \mathbf{0}$, Ada perbedaan pendapatan masyarakat nelayan di Desa Lubuk Kertang kecamatan Brandan Barat Kabupaten Langkat sebelum dan sesudah Rehabilitasi Hutan mangrove.

Uji Paired Samplet Testdengan tingkat kesalahan $\alpha=5 \%$, atau tingkat kepercayaan sebesar 95\% df (degree of freedom) atau drajat kebebasan adalah $n-1$ atau $70-1=69$. nilai $t_{\text {nit }}=-9,307$, dan Jika dibandingkan dengan nilai $\mathrm{t}_{\text {tabel }}= \pm \mathrm{t}(u / 2, \mathrm{n}-1)=$ 1,99962 , ternyata tidak benar $-1,99962 \leq-9,307 \leq 1,99962$, maka tolak $\mathrm{H}_{0}$, sehingga bisa disimpulkan bahwa ada perbedaan pendapatan masyarakat nelayan Desa Lubuk Kertang Kecamatan Brandan Barat Kabupaten Langkat sebelum sebelum dan sesudah rehabilitasi hutan mangrove.

Selanjutnya dari tabel berikut:

Tabel 2

Data Diskriftif

\begin{tabular}{|rl|r|r|r|r|}
\hline & \multicolumn{1}{|c|}{ Mean } & \multicolumn{1}{c|}{$\mathrm{N}$} & Std. Deviation & Std. Error Mean \\
\hline Pair 1 & $\begin{array}{l}\text { Pendapatan Sebelum } \\
\text { rehabilitasi Hutan Mangrove }\end{array}$ & 11.35 & 70 & 1.380 & .175 \\
& $\begin{array}{l}\text { Pendapatan Sesudah } \\
\text { Rehabilitasi Hutan Mangrove }\end{array}$ & 23.18 & 70 & 1.385 & .196 \\
\hline
\end{tabular}

Pada bagian pertama ini menyajikan deskripsi pendapatan masyarakat, yang rata-rata sebelum rehabilitasi hutan mangrove 21,35 dengan Standar Deviasi 1,380 dan setelah rehabilitasi hutan mangrove rata-rata menjadi 23,18 dengan Standar Deviasi 1,385.

Sedangkan tabel berikut,

Tabel 3

Uji Komparatif

\begin{tabular}{|ll|l|r|c|}
\hline & & N & Correlation & Sig. \\
\hline Pair 1 & $\begin{array}{l}\text { Pendapatan Sebelum rehabilitasi Hutan Mangrove \& } \\
\text { Pendapatan Sesudah Rehabilitasi Hutan Mangrove }\end{array}$ & 70 & .678 & .002 \\
\hline
\end{tabular}


Diperoleh hasil korelasi antara Pendapatan Sebelum rehabilitasi Hutan Mangrove \& Pendapatan Sesudah Rehabilitasi Hutan Mangrove yang menghasilkan angka 0,378 dengan nilai sig sebesar $0,020<\alpha=0,05$, yang berarti bahwa ada korelasi antara sebelum rehabilitasi dan setelah rehabilitasi hutan mangrove.

\section{E. KESIMPULAN}

Dari hasil penelitian yang telah dilakukan dapat disimpulkan: (1). Keadaan hutan mangrove di Desa Lubuk Kertang Kecamatan Brandan Barat dengan luas kerusakan hutan mangrove $740 \mathrm{Ha}$ dari luas seluruh hutan mangrove $1200 \mathrm{Ha}$ telah di rehabilitasi dengan baik. (2). Rusaknya hutan mangrove berdampak negatif bagi nelayan Desa lubuk Kertang, karena pendapatan mereka menurun sebelum hutan mangrove direhabilitasi, dan setelah direhabilitasi pendapatan masyarakat nelayan cukup memadai untuk memenuhi kebutuhan hidupnya,

Disarankan;

- Untuk mencegah kerusakan hutan mangrove semakin meluas, kesadaran harus muncul dari masyarakat itu sendiri. Wawasan akan pentingnya hutan mangrove bagi keseimbangan ekosistem dan juga manusia perlu terus digaungkan.

- masyarakat harus sadar untuk menjaga dan melestarikan hutan mangrove yang ada di Desa Lubuk Kertang Kecamatan Brandan Barat Kabupaten Langkat.

- Pemerintah harus segera mengeksekusi areal yang di konversi menjadi perkebunan kelapa sawit, dan segera mempercepat dan memproses serta mengawasi masalah Rehabilitasi Hutan Mangrove yang ada dan bekerja sama kepada aparat penegakan hukum, agar dapat meningkatkan kesejahteraan masyarakat di Desa Lubuk Kertang Kecamatan Brandan Barat Kabupaten Langkat.

\section{DAFTAR PUSTAKA}

Arief, Arifin.2003. Hutan Mangrove: Fungsi Dan Manfaatnya, Penerbit Kanius. Yogyakarta Bengen, D. G. 2001. Sinopsis Ekosistem Sumber Daya Alam Pesisir dan Laut. Pusat Kajian Sumber Daya Pesisir dan Lautan. IPB. Bogor. 62 p.

Bakosurtanal. 2009. Ekosistem Mangrove Kepulauan Togean, Penerbit Bakosurtanal. Dahuri, R. 2003. Keanekaragaman Hayati Laut. Jakarta: Gramedia Pustaka Utama.

Harahap, Nuddin. 2010. Penilaian Ekonomi Ekosistem Hutan Mangrove Dan Aflikasinya dalam Perencanaan Wilayah Pesisir, Penerbit Graha Ilmu. Yogyakarta.

Hasan, TWN. 2007. Harian Sinar Indonesia Baru (SIB). Kerusakan Hutan Bakau di Sumut Mencapai 62, 7 persen dari luas 83. 550 Ha, (Online), (http://hariansib.com/?p=10858,).

Irwanto. 2008. Irwantoshut.com. Hutan Mangrove dan Manfaatnya,(online), 14(http://irwantoshut.com/penelitian/hutan mangrove/).

Irwanmay, 2004. Analisis Dampak Pengalihan Lahan Konservasi Hutan Mangrove Menjadi Lahan Pertambakan Terhadap Keadaan Sosial Ekonomi Nelayan di Kecamatan Tanjung Pura kabupaten Langkat. Skripsi Medan: Fakultas Ilmu Sosial. UNIMED.

Isma, 2009. Upaya Pelestarian Ekosistem Mangrove Di Desa Secanggang Kecamatan Secanggang Kabupaten Langkat. Skripsi Medan: Fakultas Ilmu Sosial. UNIMED.

Khiatuddin, Maulida. 2003. Melestarikan Sumberdaya Air dengan Teknologi Rawa Buatan, Penerbit Gadjah Mada University Press. Yogyakarta'

Khosmin. 2005. Makalah Pertemuan Ilmiah Tahunan MAPIN XIV. Studi Perencanaan Konservasi Kawasan Mangrove Di Pesisir Selatan Kabupaten Sampang Dengan Teknologi Penginderaan Jauh Dan Sistem Informasi Geografis, (Online), (http://www.google.com/institutteknologisurabaya/,). 